\title{
THE FACTORS THAT AFFECT PUBLIC PARTICIPATION FOR EFFECTIVE MUNICIPAL SERVICE DELIVERY: A CASE OF WARD COMMITTEES
}

\author{
C. Naidoo ${ }^{1 *}$ \& R.R. Ramphal ${ }^{2}$
}

\section{ARTICLE INFO}

\section{Article details}

Submitted by authors 19 Mar 2018

Accepted for publication 8 Oct 2018

Available online 10 Dec 2018

\section{Contact details}

* Corresponding author

calvin.naidoo@ekurhuleni.gov.za

\section{Author affiliations}

1 Ekurhuleni Metropolitan

Municipality, South Africa

2 Graduate School of Business Leadership, University of South Africa, South Africa

DOI

http: / /dx.doi.org/10.7166/29-4-1948
ABSTRACT

This study sought to determine the factors that affect public participation (PP) for effective municipal service delivery by interviewing ward committee members in the Ekurhuleni Metropolitan Municipality in South Africa. Data were collected using a semi-structured questionnaire, and factor analysis and structural equation modelling were done. Seven factors were grouped as (1) facilitation of service delivery (SD) factors (i.e., public participation; accountability and transparency; people centeredness; communication; gender representation; and healthy relationships) and (2) factors that impede service delivery (i.e., power struggles). Region, race, and knowledge of the Batho Pele principles determined the perception of SD. The facilitation factors of PP for effective SD should be encouraged, while power struggles must be minimised for effective SD in South Africa.

\section{OPSOMMING}

Hierdie studie het gepoog om die faktore wat die publiek se deelname in munisipale dienslewering bepaal deur onderhoude met raadslede in die Ekurhuleni Metropool Stadsraad in Suid-Afrika te voer. Data is versamel deur 'n gedeeltelik gestruktureerde meningspeiling. Daarmee saam is faktoranalise en strukturele vergelykingsmodellering uitgevoer. Sewe faktore is saam gegroepeer as (1) diensleweringfasiliteringsfaktore (die publiek se deelname, aanspreeklikheid en deursigtigheid, mensgesentreerdheid, kommunikasie, geslag verteenwoordiging en gesonde verhoudings) en (2) faktore wat dienslewering belemmer (magstryde). Gebied, ras en kennis van die Batho Pele-beginsels het die persepsie van dienslewering bepaal. Die fasiliteringfaktore van die publiek se deelname vir doeltreffende dienslewering moet aangemoedig word, terwyl magstryde geminimeer moet word vir effektiewe dienslewering in Suid-Afrika.

\section{INTRODUCTION}

\subsection{Context}

Globally, local governments (LGs) are facing challenges in meeting their mandate of providing basic services that conform to the expectations of communities [1]; [2]. This makes LG the 'coalface' of any government's developmental strategy. In South Africa (SA), the national, provincial, and local governments work together, based on a strong principle of intergovernmental relations in the execution of their mandates, powers, and functions. This is because national and provincial governments are primarily responsible for initiating and formulating policy, while LGs operationalise such policies and transform them into tangible service delivery (SD). However, the implementation of policy is often characterised by a lack of both effective feedback mechanisms and effective management in respect of monitoring and evaluation systems [3] - a state of affairs that tends to result in an implementation gap between the design and implementation processes. 
In order to strengthen its service delivery plans, the SA government introduced the Batho Pele principles to serve as the acceptable policy and legislative framework for SD in the public service. Batho Pele is a 'tool' that is nested in strategies that are intended to enhance community or pubic participation (PP) and SD [4]. PP can be defined as a process by which potential interested and affected parties are given an opportunity to comment on, or raise issues relevant to, an application.

SA is experiencing massive backlogs, a poor skills base, and persistent SD protests, often characterised by the violent destruction of public property. One major reason for such protests appears to be the exclusion or inadequate participation of the society to be served by the integrated development plan (IDP) process. This results in dissatisfaction with services, such as running water and sanitation, electricity, roads, housing, and schools [5]; [6]; [7]; [8]; [9] but, above all, the ineffective PP process [10], as promised by municipalities. Participation [3] often works best for all concerned when each of the key interest groups is satisfied with the level of participation at which they are involved, and see value in their participation.

This study therefore sought to identify the factors of public participation for improving municipal service delivery in SA.

\section{THEORETICAL FRAMEWORK AND LITERATURE REVIEW}

\subsection{The PP process}

According to DWAF [15], the PP process must involve the activities shown in Figure 1:

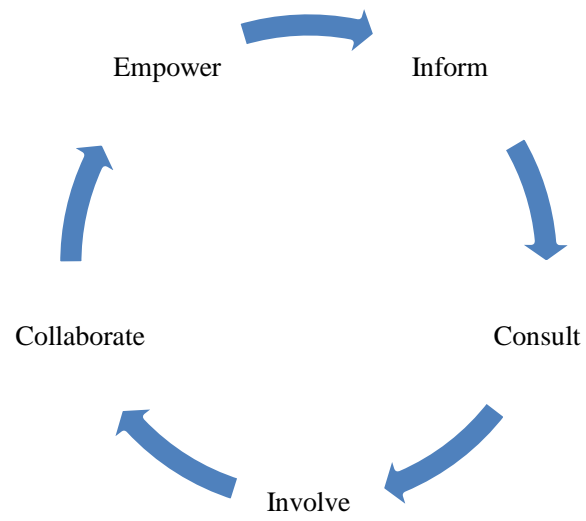

Figure 1: Activities essential to the PP process: The International Association for PP [10]

In the figure, Inform means that the community should be provided with balanced and objective information to enable people to understand the problem, the alternatives, and the possible solutions. Consult involves obtaining feedback on analysis, alternatives, and decisions. Involve means working directly with the community throughout the process to ensure that community issues and concerns are understood and considered at an early stage. The objective of Collaborate is to involve the community as equal partners in each aspect of decision-making, including the development of alternatives and the identification of the preferred solutions. Empower aims to place the final decision in the hands of the community in order to ensure that it easily accepts the decisions taken by the municipal council.

According to The World Bank [10], there are three types of community participation: passive participation, which involves only the dissemination of information to stakeholders; consultative participation, which occurs when stakeholders are consulted before a municipality makes a decision, and interactive participation, which occurs when stakeholders are involved in collaborative analysis and decision-making. 


\subsection{The existing PP framework}

In SA, the national government prescribes regulations for provincial and local governments to implement. LG in SA consists of municipalities that are governed by municipal councils that are elected every five years. LG is mandated by provincial government to carry out the prescribed pieces of legislation. LG has to implement the respective regulations and laws pertaining to local governance within the allocated timeframes for the effective governance of its citizens, and PP is one of the requirements that must be implemented. There are various sub-committees within the LG PP process that enhance the overall participation process. These include voter engagement, the budgeting process, the IDP, PP, and petitions. A local mayor may communicate directly with the public, or the public may directly contact the mayor about problems that concern them. Another important stakeholder are ward committees, which are made up of a ward councillor and a maximum of 10 people who are elected from the ward - an administrative division of a city - and who serve voluntarily on the ward committee. The municipal council determines the rules for the election of ward committee members.

The purpose of a ward committee is to assist the democratically elected representative of a ward. The ward councillor spreads important information to the community, encourages participation in the community, and is supposed to enhance effective public participation. Eikenberry (2009) asserted that effective public participation can assist municipalities to eliminate major challenges that hinder service delivery to the citizens, including corrupt practices, power struggles, and gender misrepresentation. The ward committee must make the municipal council aware of the needs and concerns of the community, and keep the community informed of developments in the municipal council. The ward committee can make recommendations to the municipal council, but it does not have decision-making powers.

Ward committee members are people within a community who know sectors of the community well, and who are thus able to assist the ward councillor with certain issues of governance. It is important to note that ward committee meetings do not replace public meetings of the ward, where all stakeholders are represented. The ward committee works with the ward councillor to ensure that the public participation process in a particular ward represents the full diversity of interests of that ward. Ward committees are meant to encourage participation by the community. As already alluded to, their job is to make the municipal council aware of the needs and concerns of residents, and to keep people informed of the activities of the municipal council. The committees spread information about what the community wants from the municipal council and what the council is doing.

Figure 2 shows the interdependency between the social actors.

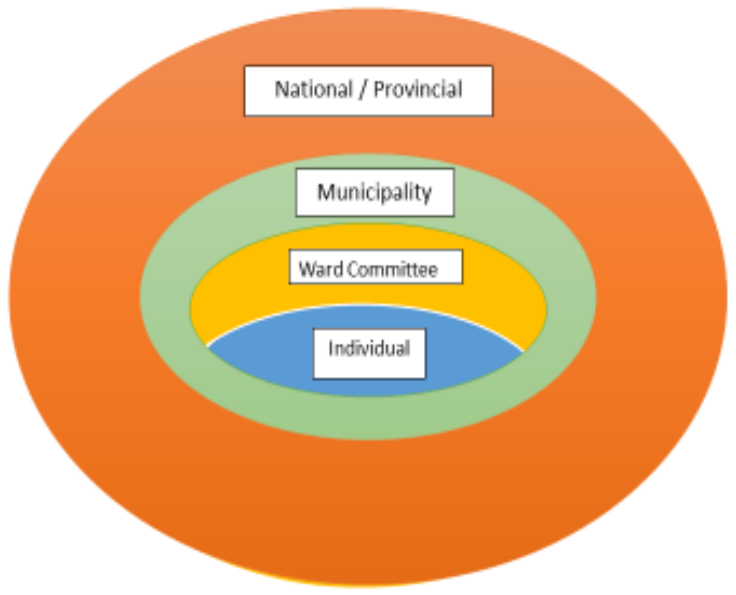

Figure 2: Interdependency within the municipal SD process (Source: Author)

At the macro level, the national government formulates policies and allocates funds for certain basic requirements and basic services. At the micro level, the delivery of public services to the members of the local community can take place through the state/province and municipality or, on behalf of the state, by a voluntary community organisation or private sector company. This bottom-up approach means that individuals or members of the local community, through PP and the ward committees that represent them, can influence the policy decision-making and the resources that affect them. 


\subsection{The integrated development plan}

Municipalities have recently adopted the integrated development plan (IDP) as a vital tool for planning and development, and to ensure that available resources are optimally used to promote sustainable economic and social development. The value of the IDP is embedded in the formulation of focused plans that are based on developmental priorities. This approach assists with curbing wasteful expenditure and breaking perpetual past spending patterns. The legislative mandate is such that the success of the IDP process hinges on public (and other stakeholder) participation, as enshrined in Chapter 2 of the Constitution, in the Bill of Rights. This mandate is visually represented in Figure 3.

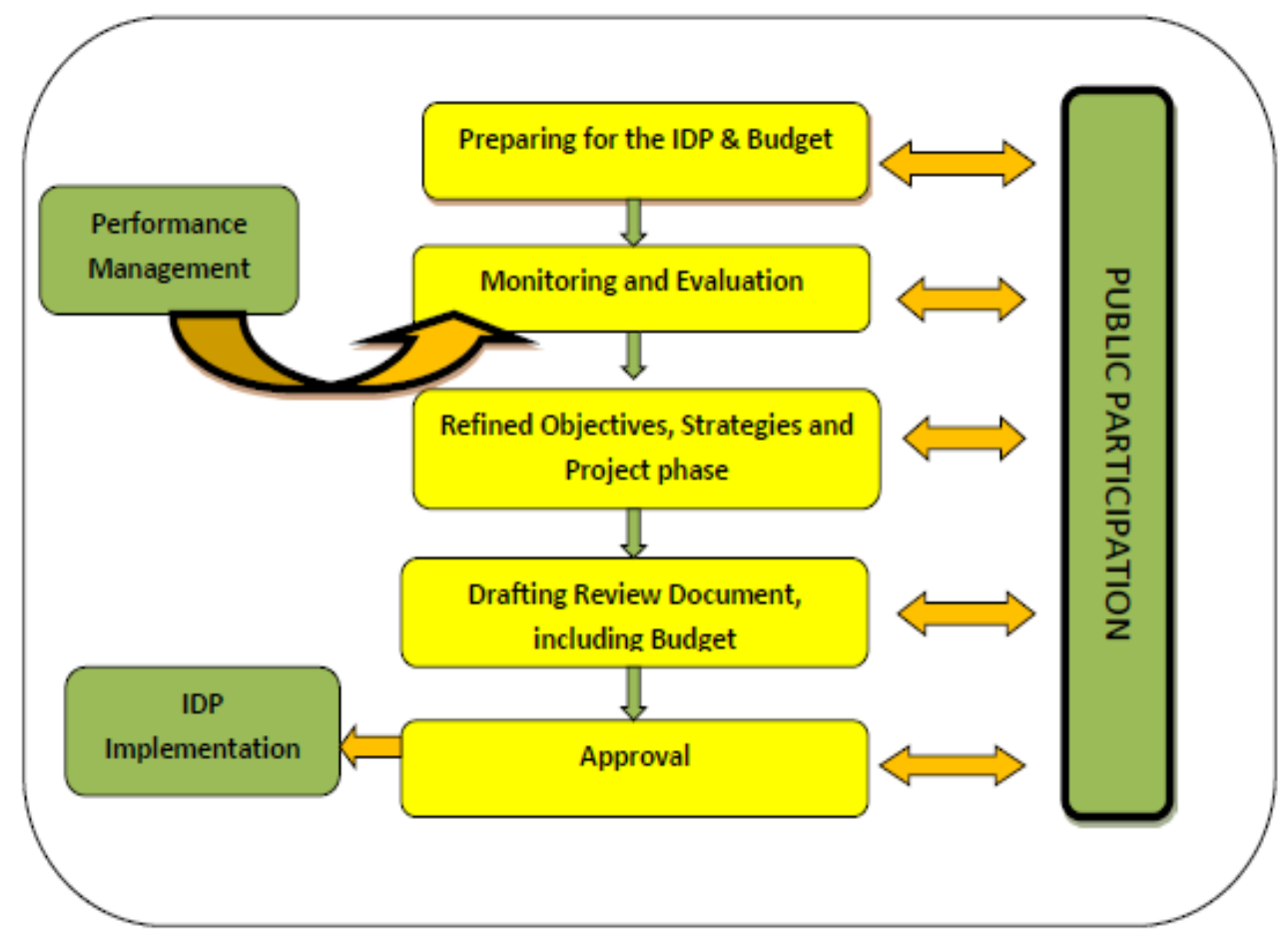

Figure 3: Intended process of IDP [12]

According to the figure, consultation is supposed to occur at every step, as the participation process is envisaged to address internal and external circumstances that impact on priority issues, objectives, strategies, projects, and programmes of integrated planning. This might therefore imply that SD protests mimic some sort of non-adherence to, or a lack of alignment with, the intended process.

\subsection{The IDP implementation framework}

In order to manage the IDP process effectively, municipalities institutionalise implementation strategies and structures for internal organisational arrangements that are meant to give effect to an inclusive participatory approach. In terms of section 74(a) of the Municipal Structures Act 58 of 1999 [79], municipalities can establish ward communities whose primary function is to act as a communication channel between the community and the municipality. Municipalities have to establish IDP representative forums, including representatives from business, labour, community, and ward committees, as well as traditional leaders or their representatives and other organisations.

Public involvement in the process of public services leads to services being perceived as better [13]. The emphasis on the importance of participation is intended to strengthen a self-development process for inclusion in the policy and decision-making process, thus creating citizen satisfaction. According to DPLG [14], the gap between the social and political spheres can be closed if they are linked, as shown in figure 4. 


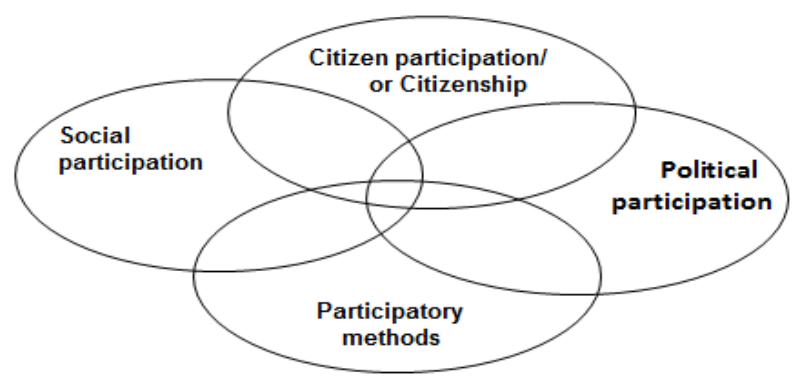

Figure 4: Linking approaches to participation [14]

The overlapping in the figure represents the links between social participation, citizenship, political participation, and participatory methods. If these are linked properly, then there is effective participation in local authorities. Barriers to participation can be overcome using workshops to facilitate the relationship between citizens and municipal officials. Blair [15] discusses a formula (represented in figure 5) that would enrich participation for both citizens and state institutions. In the figure, symbolises 'an increase in':

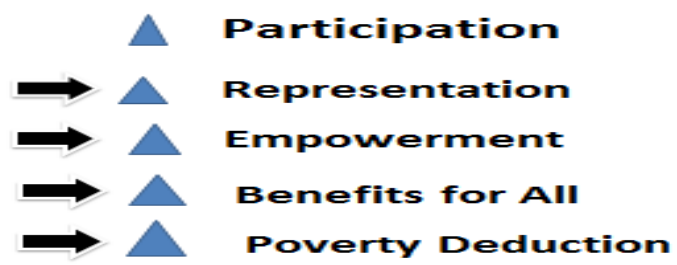

Figure 5: Formula on participation [15]

The horizontal arrows represent pressure and force for good governance [13]. Participation of democratic LGs ensures a certain degree of participation so that citizens can vote for their own local council members, thus involving them in the political process. There is a need for more representation on councils [15], which would lead to empowerment. Representation translates into benefits being fairly distributed (see [15]) and poverty deduction [16]; [17]; [18]. PP is seen as a vehicle to promote and instil a culture of good governance at the LG level [19]; [9]; [8]; [19]; [16]; [17].

Projects have to be transparent so that all stakeholders have a better understanding of the method or process employed, especially when many people are involved [20]; [18]; [8]; [9]. With collective participation, LGs must cater for participants from villages and rural areas or districts; but the problem occurs when ward committees work in silos, isolated from each other [21]; [5].

Table 1: The factors of PP for effective SD include:

\begin{tabular}{|l|l|}
\hline Factors & Literature \\
\hline $\begin{array}{l}\text { Accountability and } \\
\text { transparency }\end{array}$ & $\begin{array}{l}\text { Accountability [6]; [22]; [23]; [7]; [24]; [25] [26]; [27]; [28]; [9] } \\
\text { Transparency [29]; [30]; [31]; [8]; [32]; [17]; [1]; [33]; [34]; 35]; [36]; [37]; } \\
{[38] .}\end{array}$ \\
\hline People-centredness & {$[27] ;$ [18] to make the public more involved in municipal affairs [39]; } \\
\hline Communication & {$[40] ;[14] ;[41] ;[42]$.} \\
\hline Power struggles & {$[43] ;[44] ;[14] ;[41] ;[46] ;[47] ;[48] ;[64] ;[49]$.} \\
\hline Gender representation & {$[50] ;[51] ;[52]$.} \\
\hline $\begin{array}{l}\text { Other factors: } \\
\text { knowledge and social } \\
\text { background, } \\
\text { representativeness gap, and } \\
\text { health relationships. }\end{array}$ & {$[53] ;[54],[55] ;[56] ;[57],[58],[59] ;[60] ;[61] ;[62] ;[63] ;[35]$.} \\
$\begin{array}{l}\text { Workforce turnovers, resource } \\
\text { gap (cost) and trust gap }\end{array}$ & {$[64] ;[65] ;[51]$.} \\
\hline
\end{tabular}




\subsection{Theoretical framework}

This study was underpinned by six theories: (1) the SD theory of a configuration of technology [66], stakeholder engagement theory [67], PP budgetary theory [68], project integration theory [69], interorganisational ICT-supported reforms of SD theory [70], and systems theory. Of these, the main theories are systems theory and stakeholder theory. Systems theory allows one to view an organisation (e.g., EMM) as a social system composed of sub-systems that interact with one another in a holistic way. Viewed in terms of inputs, throughputs, and outcomes, the system requires knowledge of the basic resources and needs of the community that the local authority is providing (i.e., services such as water, electricity, sanitation, infrastructure, land, and housing). It also requires the input of various community groups working via elected officials, and hence it is political in nature.

This system does not operate in a vacuum, but takes place in an environment where various stakeholder groups are involved: central government, citizens, businesses, policing authorities, health authorities, non-governmental organisations (NGOs), pressure groups, employees, councillors, and the media. There are also social norms and various role expectations that are associated with formal organisations, such as local authorities, that have been established for the specific purpose of service delivery [71].

Stakeholder engagement is "a process in which the organisations involve the citizens or those who are affected by the decisions which it makes" [67]. The main idea is to develop an assertive understanding of the stakeholders of an organisation, what the stakeholders care about, and in what way they relate to the goal you are urging them to reach. The organisation should get to know about their stakeholders, about their complexity and scope. The enterprise-wide programmes in the organisation need a comprehensive scan to identify the stakeholders with their needs and interests. And the next step is to engage them as early as possible, for nobody likes a sudden change in his or her entity [72].

Enterprise-wide management supplies programmes that are planned and developed among themselves, and the final plan is delivered to stakeholders. Stakeholders should be involved in the programmes, and should be encouraged to participate throughout the lifecycle of every programme. [73] states that the organisation must use the right mechanisms to keep the stakeholders happy. They will not participate if not given proper guidance and ways to improve the participatory process. One must be open-minded so that the stakeholders will continue participating. Communication with stakeholders is important if the organisation is to have a good relationship with them.

In order to obtain stakeholder participation in a collaborative way, the researcher suggests that the throughput process should address the following factors: accountability and transparency, social background, health relationships, putting people first by using a people centeredness approach, open communication with all stakeholders, relevant knowledge of the social background in which the local authority operates, knowledge of the presence of power struggles, and equal gender representation in the important decision-making processes.

\section{RESEARCH DESIGN AND METHODOLOGY}

\subsection{Data}

In this study, the Ekurhuleni Metropolitan Municipality (EMM) was used as a case, and the quantitative approach and conclusive survey research design were adopted. Data were intended to be collected from a random sample of the 400 ward committee members, using anonymous online semi-structured questionnaires, but only 108 responded positively, yielding a response rate of 27 per cent. The questionnaire was validated by addressing the different types of validity: face, constructive, and content. It was also piloted using at least $40(10 \%$ of 400$)$ members of the target population, who were not used again in the main survey [74]. The sample size was chosen in accordance with the suggestion of [75] that exploratory factor analysis (EFA) requires a minimum number of cases if reliable results are to be at least five times the number of questions or variables. The pilot study helped the researcher to evaluate how the questionnaire was understood, and was therefore adjusted accordingly. All the constructs were measured on a scale of agreement ranging from $1=$ disagree to $7=$ strongly agree .

To analyse the data, the scores for the concepts making up a construct were added, and the sum divided by the number of scores added to obtain the mean scores. These mean scores of the constructs were used in the analyses. 
Figure 6 shows the model that was analysed.

Factors affecting public participation

Latent factors

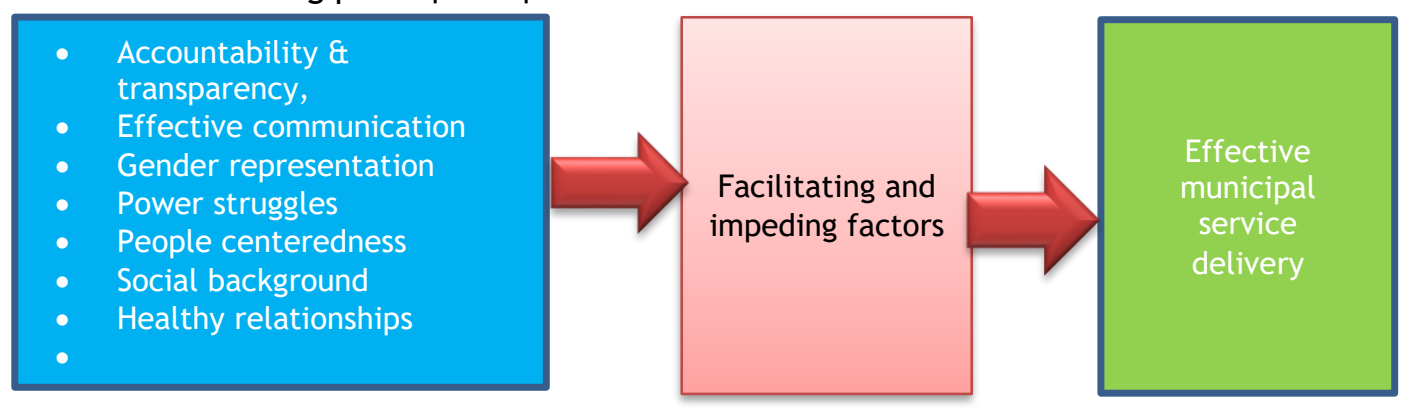

Figure 6: A model for optimising public participation in the service delivery processes

The figure indicates that public participation is affected by several factors: accountability and transparency, effective communication, gender representation, power struggles, people centredness, social background, and healthy relationships. The latent factors are the underlying factors (i.e., facilitating and impeding) that determine the level of municipal service delivery, which is the dependent variable.

Transparency is about being easy to understand, and being open, frank, and honest in all communications, transactions, and operations [6]. Accountability is about being responsible to citizens for actions taken, and about being able to explain, clarify, and justify actions. It implies that citizens have a right to know and to hold the local government to account, and that the local government has a duty to explain and account for its actions. Accountability and transparency go hand-in-hand, and involve being aware of to whom local governments are accountable, what the important pieces of information are, and how they can be communicated most effectively to the public [8]; [32]; [6]; [7].

Power-struggles are avenues for gaps in public participation and service delivery in local governments [48]; [26]; and with power-struggles, the authors assert that collective participation and transparency and accountability can hardly be realised.

[35] suggested the development of a participatory culture and capacity among public officials through communities of practice and more effective communication, while [40] linked lack of fulfilment of the goals of developmental local government to lack of effective communication between the local government and community members. This was noted as a gap that needs to be bridged if effective public participation and service delivery are to be attained [40]; [76]. Facilitating inclusivity, including gender representation, is important for effective SD [50].

[27] noted that the size of a municipal territory has a direct impact on public participation in municipal service delivery: smaller municipalities foster people-centred practices in public participation [18]; [39]. There should also be healthy relationships among all the stakeholders for effective participation and SD to take place.

\subsection{Data analysis}

Descriptive data analysis involved data summaries and descriptive statistics to identify patterns in the data - including frequencies and cross-tabulations, percentages, means, mode and standard deviation, and graphical representation of the data. Factor analysis and structural equation modelling (SEM) were done. SPSS AMOS 23.0 was used for this.

\section{RESULTS}

\subsection{Descriptive analysis}

In the sample, 64 (59.3\%) out of 108 were males. The age group 19 to 35 years had 24 (22.2\%) respondents; the majority, $75(77.8 \%)$, were between 36 and 65 years old. Most of the respondents were black, with $85(91.7 \%)$ respondents, while there were $2(2.1 \%)$ Indian, and $17(15.8 \%)$ white. Most of the ward committee members, $84(77.8 \%)$, had a matric or lower educational qualification; some had a diploma or 
degree $(21.3 \%)$. One $(.9 \%)$ omitted this question. Most respondents $(64 \%)$ indicated good or very good knowledge of Batho Pele principles, and 52.7 per cent were happy with communication on SD from the EMM offices. (The reader is cautioned that Indian committee members' perception of the presence of public participation, accountability, and transparency in their wards, and of SD in general, is based on only a very small number of observations.)

\subsection{Inferential analysis}

\subsubsection{Common factors}

Referring to Figure 6, the PP factor explained 80.58 per cent of the variation in the perception of SD (with a Cronbach's alpha coefficient of 0.85 and a mean score of 5.4). Accountability and transparency explained 79.2 per cent (with a Cronbach's alpha coefficient of 0.89 and a mean score of 6.0). The communication factor explained 52.7 per cent of the variation (with a Cronbach's alpha coefficient of 0.76 and a mean score of 4.7). Knowledge and social background explained 50.62 per cent of the variance (with a Cronbach's alpha coefficient of 0.485 and a mean score of 5.39). Power struggles explained 51.9 per cent of the variance (with a Cronbach's alpha coefficient of 0.91 and a mean score of 5.4). Health relationships explained 51.9 per cent of the variation (with a Cronbach's alpha coefficient of .85 and a mean score of 5.3), and gender representation explained 78.13 per cent of the variance (with a Cronbach's alpha coefficient of 0.829 and a mean score of 5.93).

In general, the respondents agreed with the factors of PP, accountability and transparency, people centredness, healthy relationships, and gender representation; but they only partially agreed with the factors of communication, knowledge and social background, and power struggles.

Two main factors were extracted, and all the constructs loaded on the first main factor, the PP facilitating factor. An exception was power struggles, which loaded on the second factor, the impeding factor. All the resulting factors had reliability coefficients that would be considered acceptable (rule of thumb $>0.70$ ) [77]. The impeding factor contained only power struggles (with a loading of 0.958 and a mean score of 5.01).

Public participation in effective service delivery (for ward committee members) is affected by two main factors: one related to aspects that facilitate service delivery, and the other based on aspects that impede service delivery. Facilitation of service delivery is composed of six first-order factors (public participation, accountability and transparency, people centredness, communication, gender representation, and healthy relationships), and the impeding factor is formed by one first-order factor - power struggles for effective service delivery. The impeding factor consists of items that hinder or hamper public participation in effective service delivery.

The mean score of 5.32 of the facilitating factor indicated a partial agreement with the first-order factors forming it, whereas the overall mean score of 5.01 of the second main factor, power struggles, indicated that the ward committee members partially agreed that party politics impeded service delivery in the EMM.

\subsubsection{Associations with independent variables}

The non-parametric equivalent of the independent $\mathrm{t}$-test, the Mann-Whitney $\mathrm{U}$-test, was used, as the constructs were not normally distributed.

It was also found that gender, the number of years resident in a particular area, and the education of a ward committee member did not affect their perceptions about public participation in service delivery processes. 'Region where one lives' was found to be associated with their perceptions, but only for the facilitation factors. The only factors that differed significantly according to 'region where one lives' were public participation, accountability and transparency, healthy relationships, and gender representation. Ward committee members in the disadvantaged areas agreed more strongly with public participation, accountability and transparency, healthy relationships, and gender representation than did the ward committee members from previously advantaged areas.

Race affected the perceptions of ward committee members about public participation in service delivery processes too, as far as blacks and whites and the facilitation factors were concerned. Facilitation factors involved were public participation, and accountability and transparency. Seemingly, for both factors, 
black ward committee members agreed more strongly with the view that there is public participation, and accountability and transparency in their wards than did the white ward committee members.

Knowledge of the Batho Pele principles is another important variable affecting the impeding factor. The ward committee members who indicated that they had very good knowledge of the Batho Pele principles were associated with a stronger agreement that power struggles influence public participation and service delivery issues than were the others.

\subsection{Conclusions and recommendations}

\subsubsection{Conclusions}

Seven factors were found to be involved in obtaining the largest possible public participation in service delivery processes. These were grouped as (1) factors that facilitate service delivery, and (2) factors that impede service delivery. The facilitating factors were public participation, accountability and transparency, people centredness, communication, gender representation, and healthy relationships. The impeding factor was power struggles. For 'region of residence', significant differences were present only with respect to the facilitating factor.

Ward committee members from previously disadvantaged regions agreed significantly more strongly with the facilitating factor than did ward committee members from previously advantaged regions. The factors concerned were public participation, accountability and transparency, healthy relationships, and gender representation.

Black ward committee members agreed statistically significantly more strongly with the facilitating factor, including public participation and accountability and transparency, than did white ward committee members. Very good knowledge of the Batho Pele principles - which was mostly associated with black respondents - was associated with stronger agreement that power struggles influenced public participation and service delivery issues.

\subsubsection{Recommendations}

- There should be a co-development by the community and the municipality of a comprehensive strategy to enhance the first-order factors associated with the facilitating factor. As the facilitation of effective service delivery is caused by public participation, accountability and transparency, effective communication, and gender representation, a comprehensive strategy needs to be designed to enhance the factors associated with the facilitation factor and to suppress power struggles - the factor associated with the impeding factor. Such a strategy must be the result of collaboration between the municipality and the various community groups involved with service delivery issues. The drawing up of the annual municipal budget could serve as a good example of collaborative planning.

- In the light of the point above, the annual budget should be a collaborative planning issue between the municipality and the various stakeholder public groups, through which it is subjected to open communication, and where all involved can give their honest opinion about the money allocated to the various services

\section{FUTURE RESEARCH}

Specific research suggestions that emerged from this empirical investigation include the following:

- $\quad$ More items relating to knowledge and social background need to be included.

- The actual reasons why respondents differed statistically significantly from one another in some of the latent factors involved needs to be further investigated. This could possibly be done by using a qualitative paradigm in which people are asked specific questions about why they agreed or disagreed with particular items.

- Investigation could be undertaken into what strategies are available to counteract the political power struggles that accompany PP. 


\section{REFERENCES}

[1] Barnes, M., Newman, J. and Sullivan. 2007. Power, participation and political renewal. Bristol, UK: Policy Press.

[2] Ritzer, G. 2008. Sociological theory. $7^{\mathrm{h}}$ ed. Boston: McGraw-Hill.

[3] Scott, R. 2009. An analysis of PP in the SAN legislative section. Masters thesis in Public Administration. Stellenbosch: University of Stellenbosch.

[4] Ababio, E.P. 2004. Enhancing community participation in developmental local government for improved SD. Journal of Public Administration, page no. 39(2)

[5] Pilietines G.I. 2011. Accessed May 3, 2011 at http://www.civitas.lt

[6] Petukienè, E. 2010. Klientu dalyvavimo viešosiose paslaugose valdymas Lietuvos seniūnijose. Daktaro disertacija. Kaunas: KTU.

[7] Viešasis V. and Smalskys, V. (eds). 2010. Citizen participation in the local public service provision and Quality improvements. Vilnius: Mykolo Romerio Universiteto Leidybos Centras.

[8] Howlett, M. and J. Rayner. 2006. Globalization and Governance Capacity: Explaining Divergence in National Forest Programs as Instances of "Next-Generation" Regulation in Canada and Europe. Governance: An International Journal of Policy, Administration, and Institutions, 19, 2, 251-275.

[9] Eikenberry, A.M. 2009. Philanthropy, voluntary association and governance beyond the state: Giving circles and challenges for democracy. Administration \& Society, 38(9), pp. 915-919.

[10] Pillay, U., Tomlinson, R. and du Toit, J. (eds). 2006. Democracy and delivery: Urban policy in SA. SA: HSRC Press Cape Town.

[11] Department of Water Affairs and Forestry (DWAF). 2001. Stakeholders participation. Pretoria: DWAF.

[12] Department of Provincial and Local Government. 2007. National Policy Framework for Public Participation. Pretoria SA:.

[13] Bovaird, T. and Downe, J. 2008. Innovation in public engagement and co-production of services, local government modernisation. White Paper policy paper.

[14] Gaventa, J. and Valderrama, C. 1999. Participation, citizens and local governance. Institute of Development Studies. June 21-24, 1999, Brighton, UK

[15] Blair, H.W. 2000. Participation and accountability at the periphery: Democratic local government in six countries. World Development, Vol 28,No 1pp. 21-39, http://dx.doi.org/10.1016/S0305-750X(99)00109-6.

[16] Nyalunga, D. 2011. An enabling environment for PP in local government. International NGO Journal, 1(5), pp. 2-6.

[17] Warner, M.E. and Hefetz, A. 2010. Service characteristics and contracting: The importance of citizen interest and competition, in The Municipal Year Book 2010. Washington, DC: International City County Management Association, pp. 19-27.

[18] Bozeman, B. (ed.). 2010. Public values and public interest: Counterbalancing economic individualism. Washington, DC: Georgetown University Press.

[19] Becker, C. 2000. Service recovery strategies: The impact of cultural differences. Journal of Hospitality \& Tourism Research, 24(4), pp. 526-538.

[20] Connor, T. 2003. Politics of planning and participation. Beverly Hills: Sage.

[21] Robison, M. 1998. Democracy, participation, and public policy: The policy of institutional design, in Robison, M. \& White, G. (eds). The Democratic Development State. Oxford: page 1-10,0xford University Press.

[22] Institute of Fundraising. n.d. Defining accountability and transparency \& key principles. Available at: http://www.institute-of-fundraising.org.uk/code-of-fundraising-practice/guidance/accountability-andtransparency-guidance/defining-accountability-and-transparency-and-key-principles/. Accessed 2 June 2016.

[23] Raipa, A. and Petukienè, E. 2009. Klientu dalyvavimas viešosiose paslaugose: bendrasis paslaugu kūrimas. Viešoji politika ir administravimas, 27, pp. 54-62.

[24] Meng, B. 2008. Pathways towards citizen participation: Insights on community planning in Cambodian cities. Journal of Contemporary Easter Asia, 7(2), pp. 49-55.

[25] United Nations. 2011. Good governance practices for the protection of human rights. Office of the United Nations High Commissioner for Human Rights.

[26] United Nations. 2012. Good governance practices for the protection of human rights. Office of the United Nations High Commissioner for Human Rights.

[27] Glaser, M.A., Yeager, S.J. and Parker, L.E. 2008. Involving citizens in the decisions of government and community: Neighborhood-based vs. government-based citizen engagement. Public Administration Review, Summer, pp. 177-217.

[28] Siebert, H. 2008. Economics of the environment: Theory and policy. Berlin: Springer- Verlag.

[29] Transparency International. 2008. Corruption perception index. Available at

http://www.transparency.org/policy_research/surveys_indices/cpi/2008. Accessed 28 November 2014.

[30] Eicher, S. 2009. Corruption in international business: The challenge of cultural and legal diversity. Surrey: Ashgate Publishing Ltd.

[31] Kranacher, M., Riley, R. and Wells, J.T. 2011. Forensic accounting and fraud examination. New York: ACFE.

[32] Duffy, B., Vince, J. \& Page, L. 2008. Searching for the impact of empowerment. London: Ipsos MORI Social Research Institute.

[33] Albrecht, S., Kohlrausch, N. and Kubicek, H. 2008. eParticipation: Electronic participation of citizens and the business community in eGovernment. Bremen: University of Bremen. 
[34] Parker, S., Spires, P., Farook, F. and Mean, M. 2009. State of trust: How to build better relationships between councils and the public. London: DEMOS.

[35] Urbinati, N. and Warren, M.E. 2008. The concept of representation in contemporary democratic theory. Annual Review of Political Science, 11, pp. 387-412.

[36] Cornwall, A. 2008. Democratising engagement. London: DEMOS.

[37] Skidmore, P. and Bound, K. 2008. Everyday democracy index. London: DEMOS.

[38] Creasy, S., Gavelin, K. and Potter, D. 2008. Everybody needs good neighbours? London: Involve.

[39] Homsy, G.C. and Warner, M.E. 2014. Intermunicipal cooperation: The growing reform, in The Municipal Yearbook 2014.Page 1-13 Washington, DC: International City County Management Association, .

[40] Dudley, L. 2009. Communication and economic growth. European Economic Growth Review 53, pp. 595-619.

[41] Mukandala, R.S. 1998. Decentralisation and democratisation in Tanzania. Occasional paper no. 46, University of lowa. USA

[42] Mannor, J. and Crook, R.C. 1998. Democracy and decentralisation in South Asia and West Africa: Participation, accountability and performance. UK: Cambridge University Press.

[43] Morgan, G. 1997. Images of organisation. London: SAGE.

[44] Schonwalder, A.G. 1997. New democratic spaces at the grassroots? Popular participation in Latin American local governments, Development and Change, 28(4), pp. 753-770.

[45] Abraham, A. and Platteau, J.P. 2004. Participatory development: When culture creeps. Stanford, Stanford University Press.

[46] Morris, A. and Staggenborg, S. 2004. Leader in social movements. Princeton: Princeton University Press.

[47] Leopold, E. and McDonald, D.A. 2012. Municipal socialism then and now: Some lessons for the Global South. Third World Quarterly, 33(10), pp. 1837-1853.

[48] Hassan Abbas, "The Dynamics of the Uprising in Syria," Arab Reform Initiative, Arab Reform Brief, No. 51, October 2011

[49] Purdon, C. 2008. Bridging the gender gap in the 21st century: Strategies to increase women's participation in municipal consultation processes. The IULA Worldwide.

[50] Nanz, P. and Dalferth, S. 2009. Making their voice heard - and listened to: Some thoughts on PP in Europe, in Ruano-Borbalan, J.-C. (ed.), Paris: Presse de Sciences Po. Page 1-12

[51] Dörr, N. 2008. Deliberative discussion, language, and efficiency in the world social forum. Mobilisation: An International Journal, 13(4), pp. 395-410.

[52] Moreno-Torres, M. 2011. SD in a difficult environment: The child-friendly community initiative in Sudan. DFID Policy Division. London UK.

[53] OECD/DAC. 2009b. Synthesis paper on good practice: The challenge for donors. Paris: Fragile States Group, Work Stream on SD, draft paper, OECD.

[54] OECD/DAC. 2010b. Whole of government approaches to fragile states, Paris: OECD.

[55] Powell, M. and Kleinmann, D.L. 2008. Building citizen capacities for participation in nanotechnology decisionmaking: The democratic virtues of the consensus conference model. Public Understanding of Science, 17, pp. 329-348.

[56] World Bank. 2011. World development report 2004: Making services work for poor people. Washington, DC: World Bank.

[57] World Bank. 2012. Community service recovery. Background paper for World Development Report. Washington, DC: World Bank.

[58] World Bank Group. 2013. World Bank Group Work in Low-Income Countries under Stress: A Task Force Report in Rogers, P.N. (Ed.), World Bank Group Work in Low-income Countries under Stress: A Task Force Report. World Bank.

[59] Devas, N. and Grant, U. 2003. Local government decision making - citizens participation and local accountability: Some evidence from Kenya and Uganda. International Development Department, University of Birmingham, Edgbaston, Birmingham, UK John Wiley and Sons Ltd, 23(4), 307-316.

[60] Guijt, I. \& Shah, M.K. 1998. The myth of community: Gender issues in participatory development. London: ITDG Publications.

[61] Hulume, D. and Siddique, N. 1997. Central-local relations and responsibilities in Bangladesh: Experiments with the organisation, management and delivery of services. ESCOR Research Project. UK Department for International Development DFID

[62] Thompson, D.F. 2008. Deliberative democratic theory and empirical political science. Annual Review of Political Science, 11, pp. 497-520.

[63] OECD/DAC. 2008. SD concept note. Paris: Fragile States Group, OECD.

[64] World Bank. 2010. World development report 2010: Development and the next generation. Washington, DC: World Bank.

[65] Norris, P. 2001 Civil engagement, information poverty. Cambridge: Cambridge University Press.

[66] Kerlinger, L. 2002. Governing at local level. New York: Simon and Schuster.

[67] Stones, A. 2001. Citizen science: A study of people. London: Routledge.

[68] Theron, F. 2003. Confusion of concepts rules out blanket participation strategy: Cape Times, 9 October.

[69] Young, F. 2004. Local government finance. New York: Basic Books.

[70] Bekkers, V. 2005. The governance of back office integration in e-government: Some Dutch experiences, in Wimmer, M. et al. (eds). Electronic government. Heidelberg: Springer, pp. 12-25.

[71] Loock, C.F., Grobler, B.R. and Mestry, R. 2006. Human resource management in education: Rebalancing the scales. Pretoria: Van Schaik. 
[72] Hemson, D. 2007. Can participation make a difference? Prospects for people's participation in planning. Critical Dialogue - Public Participation in Review, 3(1) 9-15.

[73] Millan, N. 2001. Administrative behaviors - at local government. New York, NY: Free Press.

[74] Connelly, L.M. 2008. Medsurg Nursing. Official Journal of the Academy of Medical-Surgical Nurses, 17(6), pp. 411-412.

[75] Mundfrom, D.J., Shaw, D.G. and Ke, T.L. 2005. Minimum sample size recommendations for conducting factor analyses. International Journal of Testing, 5(2), pp.159-168.

[76] Lu, Y. 2009. Challenges for China's international communication. Nottingham: University of Nottingham.

[77] Nunnally, J.C. \& Bernstein, I.H. 1994. Psychometric theory (3rd ed.). New York: McGraw-Hill.

[78] Republic of South Africa: Municipal Structure Act. 1998. SA. www.policy.org.za . 